\title{
Iron Deficit Anemia As a Risk Factor of Asthma
}

\author{
Maghreb S Alkhateeb $(\mathrm{DCH})^{1}$, Hassan M Khalil $(\mathrm{DCH})^{2}$, Mezher Mohsin Kadhim \\ $(\mathrm{DCH})^{3}$ and Jalil I Alezzi (FICMS $)^{4}$
}

Abstract

Background: There are many risk factor for asthma occurrence like gender, atopy and infection. Trace elements like iron, magnesium and zinc play a role in decreasing airway hyperreponsiveness.

Objective: To evaluate iron deficiency anemia as a risk factor for childhood asthma and its likely outcome on lung functions.

Patients and Methods: Across-sectional comparative study was conducted on 200 children, 6-14 years old who admitted to the outpatient pediatric clinics and emergency department of Albatool Teaching hospital in Diyala governorate from Oct. 2017 to Oct 2018, they were categorized into: group I: 100 children with IDA-who was subdivided into group Ia: Asthmatic children and group I b: Non asthmatic children. Group II: 100 children without IDA, subdivided into group II a: asthmatic children and group II b: non-asthmatic children. Results: Children with asthma in group I a the male to female ratio was 1.75/1.0 and in group II $\mathrm{b}$ the ratio was 1.4/1.0.The anemic group with asthma constitute $66 \%$ of group I, while in group II the asthmatic children constituted $24 \%$ of included children. Anemic asthmatic children had significant difference regarding pulmonary function tests in comparison to non-anemic asthmatics.

Conclusion: Anemic asthmatics group constituted 66\%, and anemia had significant detrimental effects on pulmonary function tests in comparison to non-anemic asthmatics.

Keywords: Children Asthma, Fe deficiency.

Corresponding Author: alwardamagreb@yahoo.com

Received: $7^{\text {th }}$ August 2019

Accepted: $22^{\text {th }}$ September 2019

DOI:https://doi.org/10.26505/DJM.17024860807

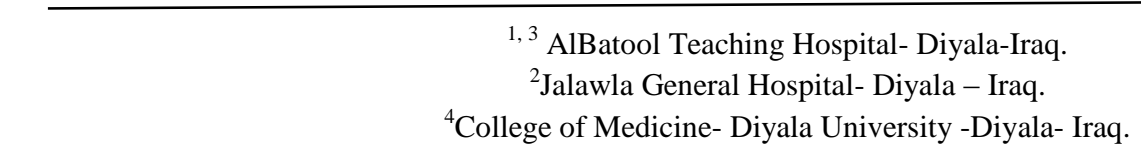

\section{Introduction}

The known risk factors for asthma, are gender, airway hyper-reactivity, atopy, allergens, infections, tobacco smoke, obesity, and perinatal factors, [1-4]. Iron state is recognized to influence the capacity to oxygenate tissues and produce energy, but how iron influences immune and nonimmune-started inflammatory progressions is indistinct. Iron and Zinc displayed significant decrease in delayed type hypersensitivity and 
retain important anti-asthmatic effect which may be attributed to its immunomodulatory and anti-inflammatory features[4,5-8], greater iron stocks were inversely connected with asthma and lesser body iron and higher tissue iron need were linked with lower lung function [5,7,9-12]. Pathophysiologic occasions creating asthma, including inflammation, upsurges in Th2 cells, and muscle tightening, can associate with iron obtainability $[2,3,8]$. Preservation of iron homeostasis is of extreme importance for the respiratory physiology and pathophysiology as well as local iron deficit or accumulation may result in certain respiratory function impairment Forced Expiratory Volume in one second (FEV1,) Forced Vital Capacity (FVC), FEV1/FCV and Peak Expiratory Flow (PEF). [12,13-17].It had been shown that iron-supplemented diet had markedly decreased allergen-induced airway hyperreactivity, by decreasing mast cell activation [3,4,17-19]. Identification of further treatments that could preclude or decline the rigorousness of asthma would offer a chief progress in clinical attention of patients with allergen-started asthma [20, 21]. The objective of this study was to study iron deficit anemia (IDA) as a risk factor for childhood asthma and its probable effect on lung functions.

\section{Patients and Methods}

This cross sectional comparative study was carried out on 200 youngsters in the age group of 6-14 years who attend to the outpatient pediatric clinic and emergency department of Albatool Teaching hospital with upper or lower lung infection, One hundred patients with IDA and 100 children without IDA and they were scrutinized and examined for judgement of bronchial asthma during the period from Oct 2017 to Oct 2018. The patients were categorized into:

Group I: 100 children with IDA that was subdivided into:

Group Ia: asthmatic children.

Group Ib: non asthmatic children.

Group II: 100 children without IDA that was divided into:

Group IIa: asthmatic children.

Group IIb: non-asthmatic children.

\section{Inclusion criteria}

A.The judgment of bronchial asthma in children was based on criteria mentioned in previous studies [17], [18], [19]:

1.A history of recurrent or chronic symptoms characteristic of asthma.

2.The findings on physical check of distinctive musical wheezing (present in relationship with signs and absent when signs resolution).

3.A post-bronchodilator increase in FEV1 of $>12 \%$.

B.Principles for identification of anemic children: The child is deliberated to be anemic if $\mathrm{Hb}$ value $<11 \mathrm{gm} / \mathrm{dL}$. Blood film showed hypochromic microcytic RBCs and MCV < 72fLRed cell distribution width > 15 $\%$.The serum $\mathrm{Fe}<30 \mu \mathrm{g} / \mathrm{dL}$ and serum ferritin level $<12 \mu \mathrm{g} / \mathrm{dl}[5,10]$.

\section{Exclusion criteria}

Anemia other than IDA.

Chronic lung illness other than asthma.

Heart disease. 
Liver disease.

Kidney disease

All children were exposed to:

I.Complete history taking and physical check: With distinctive care to recurrent attacks, cough and shortness of breath, wheezy, dyspnea and chest tension, Tachypnea, marks of hyperinflation, lengthy expiratory period, Expiratory Rhonchi and pallor. Body mass index(BMI) was calculated using the following formula: $\mathrm{BMI}=$ Weight/Height2 in meter square.

II. Laboratory investigations:

Full blood picture.

Serum ferritin value.

Kidney function tests.

Hepatic function checks

III. Chest roentgenogram PA: was done to eliminate other etiologies of wheeziness additional than asthma.

Spirometer was used to check the forced expiratory volume in one second (FEV 1) and forced vital capacity (FVC) using principles laid by Miller [15]. Calculation of Peak expiratory flow (PEF) done by the following equation The equation for calculation of predicted normal values for PEF for males and females are as follows: [12]

Males: PEF $(\mathrm{L} \cdot \mathrm{s}-1)=(6.14 \times$ height $)-$ $(0.043 \times$ age $)+0.15$

Females: PEF $(\mathrm{L} \cdot \mathrm{s}-1)=(5.50 \times$ height $)-$ $(0.030 \times$ age $)-1.11$

\section{Ethics consent}

The study rules and the methods were carried out agreeing to values of the Statement of Helsinki, as well as revised and accepted by the College of medicine, university of Diyala Ethics Research Committee. Oral agreements were also received from the parents and caretakers of children intricate in the study.

\section{Statistical analysis}

Records were evaluated using Statistical Package for Social Sciences version 23(SPSS Inc., Chicago, IL, USA). Qualitative statistics were presented as number and percent. Appraisal between groups was completed by Chi-Square test. Quantifiable records were offered as mean $\pm \mathrm{SD}$. Student's t-test was used to compare between two groups. Pearson's correlation coefficient was used to check association between variables. $\mathrm{P}<0.05$ was considered statistically noteworthy.

\section{Results}

Table (1) showed the characteristics variables of two hundred studied children ,where children with asthma in group Ia the male to female ratio was 1.75/1.0and in group IIb the ratio was 1.4/1.0 .The anemic group with asthma constitute $66 \%$ of group I ,while in group II the asthmatic children constituted 24\%. Table (2) showed the relationship between hemoglobin and serum ferritin value with respiratory function limits among 100 anemic group I (Ia and Ib, where children with low $\mathrm{Hb}$ and low serum ferritin and asthma had more pronounced deterioration of pulmonary function on spirometry study $\mathrm{P}$ value $<0.05$. Table (3) showed association among groups (Ia) and (IIa) regarding pulmonary functions, where those with asthma with anemia had more pronounced deterioration of pulmonary 
function on spirometry study than asthma alone $\mathrm{P}$ value $<0.05$.

Table (1): Characteristics variables of the children in the present study

\begin{tabular}{|c|c|c|c|c|c|c|c|c|c|}
\hline \multirow[t]{2}{*}{ Variable } & \multirow[t]{2}{*}{ Groups } & \multirow[t]{2}{*}{ Age } & \multirow[t]{2}{*}{ Male } & \multirow[t]{2}{*}{ Female } & \multicolumn{2}{|c|}{ Asthma } & \multicolumn{2}{|c|}{$B M I$} & \multirow[t]{2}{*}{$P$ value } \\
\hline & & & & & Yes & No & $>25$ & $<25$ & \\
\hline \multirow[t]{2}{*}{ Anemic } & Group Ia & $6-14$ & $42(63.6 \%)$ & $24(36.3 \%)$ & $66 \%^{\mathrm{a}}$ & & $26(39.3 \%)$ & $40(60.6 \%)$ & \\
\hline & Group Ib & $6-14$ & $26(76.4 \%)$ & $8(23.5 \%)$ & & $34 \%$ & $10(29.4 \%)$ & $24(70.5 \%)$ & \\
\hline Total & 100 & & $68 \%$ & $32 \%$ & \multicolumn{2}{|c|}{$100 \%$} & & & \\
\hline \multirow{2}{*}{$\begin{array}{c}\text { None } \\
\text { anemic }\end{array}$} & Group IIa & $6-14$ & $14(58.3 \%)$ & $10(41.6 \%)$ & $24 \%$ & & $8(33.3 \%)$ & $16(66.6 \%)$ & \\
\hline & Group IIb & $6-14$ & $36(47.3 \%)$ & $40(52.6 \%)$ & & $76 \%^{b}$ & $12(15.7 \%)$ & $64(84.2 \%)$ & \\
\hline Total & \multicolumn{2}{|c|}{100} & $50 \%$ & $50 \%$ & \multicolumn{2}{|c|}{$100 \%$} & & & \\
\hline
\end{tabular}

$* \mathrm{p}$ value $=.001$

$* \mathrm{p}$ value $=.000$ 
Table (2): Relationship between hemoglobin and serum ferritin level with pulmonary function parameters among anemic group

\begin{tabular}{|c|c|c|c|c|c|}
\hline Lab. test & Group I & $\begin{array}{l}\text { Pulmonary } \\
\text { functions }\end{array}$ & $\begin{array}{l}\text { No. of } \\
\text { children }\end{array}$ & Measurement & Pvalue \\
\hline \multirow{8}{*}{$\begin{array}{l}\text { Low } \mathrm{Hb} \text { level } \\
\text { Low serum ferritin }\end{array}$} & \multirow[t]{8}{*}{ Ia } & \multirow[t]{2}{*}{ FVC } & 12 & Average standards for age & \multirow{2}{*}{.000} \\
\hline & & & 54 & Below average standards for age & \\
\hline & & \multirow[t]{2}{*}{$\mathrm{FEV}_{1}$} & 8 & Average standards for age & \multirow[t]{2}{*}{.000} \\
\hline & & & 58 & Below average standards for age & \\
\hline & & \multirow[t]{2}{*}{$\mathrm{FEV}_{1} / \mathrm{FVC}$} & 10 & Average standards for age & \multirow[t]{2}{*}{.000} \\
\hline & & & 56 & Below average standards for age & \\
\hline & & \multirow[t]{2}{*}{ PEF } & 8 & Average standards for age & \multirow[t]{2}{*}{.000} \\
\hline & & & 58 & Below average values for age & \\
\hline \multirow{8}{*}{$\begin{array}{l}\text { Low } \mathrm{Hb} \text { level } \\
\text { Low serum ferritin }\end{array}$} & \multirow[t]{8}{*}{$\mathrm{Ib}$} & \multirow[t]{2}{*}{$\mathrm{FVC}$} & 32 & Average standards for age & \multirow{8}{*}{.000} \\
\hline & & & 2 & Below average standards for age & \\
\hline & & \multirow[t]{2}{*}{$\mathrm{FEV}_{1}$} & 30 & Average standards for age & \\
\hline & & & 4 & Below average standards for age & \\
\hline & & \multirow[t]{2}{*}{$\mathrm{FEV}_{1} / \mathrm{FVC}$} & 31 & Average standards for age & \\
\hline & & & 3 & Below average standards for age & \\
\hline & & \multirow[t]{2}{*}{ PEF } & 32 & Average standards for age & \\
\hline & & & 2 & Below average standards for age & \\
\hline
\end{tabular}


Table (3): Association between groups (Ia) and (IIa) concerning respiratory functions

\begin{tabular}{|l|c|c||c||c|}
\hline \multicolumn{2}{|l|}{ Group } & \multicolumn{1}{|l|}{ FVC } & FEV $_{\mathbf{1}}$ & FEV $_{\mathbf{1}}$ /FVC \\
\hline \hline $\begin{array}{l}\text { GROUP (Ia) } \\
\text { No = 66 } \\
\text { Anemic asthmatic }\end{array}$ & Range & $(53-72)$ & $(53-76)$ & $(54-65)$ \\
\hline \hline $\begin{array}{l}\text { GROUP (IIa) } \\
\text { No = 24 } \\
\text { Non anemic asthmatic }\end{array}$ & Mean + SD & $61.2 \pm 9.5$ & $57.5 \pm 8.3$ & $52.3 \pm 10.0$ \\
\cline { 2 - 5 }$P$ value & Mean + SD & $71.0 \pm 8.4$ & $63.0 \pm 6.4$ & $61.4 \pm 8.0$ \\
\hline \hline
\end{tabular}

There is a statistically substantial variance between group Ia and group IIa concerning respiratory function limitations) FVC, EEV1, FEV1/FVC) $(\mathrm{P}<0.05)$ as it was superior ingroup IIa.

\section{Discussion}

Asthma affects > 300 million individuals worldwide. Anemia and lung infections are public harms among preliminary schoolchildren and a compound kin exists between iron state and infection. In this study the ages of group I fluctuated from 6 to 14 years and mean was $10.2 \pm 3.1$ and in group II their ages fluctuated from 6 to 14 years and mean was $10.9 \pm 3.2$.

There was no significant statistical variance between groups I and group II concerning age $(\mathrm{P}>0.05)$. This study showed more boys affected with asthma than girls which is statistically significant ( $p$ $<0.05$ ) as it it was noted by many studies $[2$, 7, 17]. Although BMI is an important risk factor of asthma $[2,5,20]$ in this study we did not find any important statistical variance between studied groups ( $\mathrm{P}$ value $>0.05)$. This may be due to different sampling technique and probably related to decreased obesity and overweight in the studied sample. Iron and anemia are accompanying with weakened immunocompetence, which result in augmented morbidity [8].The $\mathrm{Hb}$ assists oxygen $(\mathrm{O} 2)$ and $\mathrm{CO} 2$ transport. It transports and deactivates nitric oxide (NO) and does the part of the shield as well as accountable for steadying the oxygen tension in the tissues [10.11].We noticed that asthma was significantly higher in group Ia than in group IIa which is in accordance with other studies as Fe deficiency is a risk factor for asthma $[1,3,4,8,9]$.

Respiratory function checks afford appreciated evidence about the status of an individual's pulmonary system and effort capability $[1,3,9,14$,$] . In the current study$ there was a significant connection between $\mathrm{Hb}$ level and respiratory function checks in anemic asthmatic group Ia, in comparison to non-anemics as low $\mathrm{Hb}$ level plays significant role in cardiopulmonary function . Similarly there was a substantial association between serum ferritin value and FVC, FEV, FEV1/EVC \& PEF. In the current study there was a significant statistical variance between group Ia and group IIa concerning respiratory 
function factors $(\mathrm{P}<0.05)$, this is explained on the basis of physiologic effects of low $\mathrm{Hb}$ on cardiopulmonary dynamics. Low $\mathrm{Hb}$ upsets the immune structures of the body and diminishes immunity, so increases the risk of infection especially viruses, which in turn increase the risk of asthma. A reduction in power of breathing muscles including diaphragm decreases the lung functions as well as peak expiratory flow rate, FEV1 [15].

Extreme intentional aeriation is distinctly decreased due to the reduced deepness of breathing as well. It was concluded that IDA may be reflected as an ancillary hazard reason for development of asthmatic bouts in children.IDA may have an adverse outcome on spirometry outcomes in asthmatic children that may prime to an augmented harshness of asthmatic bouts.

Based on this study we can recommend the followings:

1.Hb level should be checked for every asthmatic child and if it is low, proper investigations for the type of anemia should be initiated to exclude IDA.

2. Prevention of IDA is important since it is common in our community, to improve immunity and decrease the risk of asthma and its severity.

Limitations of the study: The sample was small, since larger sample needed to generalize the recommendations. Absence of PFT lab in our hospital and the patients need to be sent to another hospital to do the test.

\section{References}

[1]Brigham EP, McCormack MC, Takemoto $\mathrm{CM}$, Matsui EC: Iron status is associated with asthma and lung function in US women, PLoS One. 2015 Feb17;10(2):e0117545. doi: 10.1371 .

[2]GINA updated Global Strategy for Asthma Diagnosis and Prevention (2009) Available at: <www.ginasthma.org> [3]Corbett SS, Drewett RF: To what extent is failure to thrive in infancy associated with poorer cognitive development? A review and meta-analysis. J Child Psychol Psychiatry. $2004 ; 45(3): 641-54$.

[4]K Ramakrishnan, P.S. Harish Hemoglobin level as a risk factor for lower respiratory tract infection Indian J. Pediatr., 73 (10) (2006), pp. 881-883.

[5]Sandoval C, Jayabose S, Eden AN. Trends in diagnosis and management of iron deficiency during infancy and early childhood. Hematol Oncol Clin North Am 2004; 18:1423.

[6]Miller MR, Hankinson J, Brusasco V. Standardizations of spirometry. Eur Respir J 2005; 26:319.

[7]E.D Bateman, S.S. Hurd, P.J. Barnes, etal.Global strategy for asthma management and prevention: GINA executive summary.Eur. Respir. J., 31 (1) (2008), pp. 143-178.

[8]H Thibault, P. Galan, F. Selz, etal.The immune response in iron-deficient young children: effect of iron supplementation on cell-mediated immunity Eur. J. Pediatr., 152 (2) (1993), pp. 120-124.

[9]Ramakrishnan, Ashwin Borade :Anemia as a risk factor for childhood asthma Lung India, $27 \quad$ (2) (2010), pp. 5153CrossRefView. 
[10]Baker RD, Greer FR, Committee on Nutrition American Academy of Pediatrics. Diagnosis and prevention of iron deficiency and iron-deficiency anemia in infants and young children (0-3 years of age). Pediatrics 2010; 126:1040.

[11]Hale LP, Kant EP, Greer PK, Foster WM.:Iron supplementation decreases severity of allergic inflammation in murine lung; PLoS One. 2012;7(9):e45667. doi: 10.1371/journal.pone.0045667.

[12]Quanjer PH, Tammeling GJ, Cotes JE, et al. Lung volumes and forced ventilator flows. Report Working Party Standardization of Lung Function Tests, European Community for Steel and Coal. Official Statement of the European Respiratory Society. Eur Respir J Suppl1993;16:5-40.

[13]Ghio AJ: Asthma as a disruption in iron homeostasis, Biometals. 2016 Oct;29(5):75179. doi: 10.1007/s10534-016-9948-y.

[14] S.N. Du, M. Yeshwanth, T.S. Raghuveer :Effect of iron deficiency anaemia on pulmonary function in children.J. Lung India, 12 (4) (1994), pp. 168-173.

[15] Miller MR, Hankinson J, Brusasco V, et al. Standardisation of spirometry. Eur Respir J 2005; 26:319.

[16]Dombkowski KJ, Hassan F, Wasilevich EA, Clark SJ. Spirometry use among pediatric primary care physicians. Pediatrics 2010; 126:682.

[17]Naepp Expert Panel Report III: Guidelines for the Diagnosis and Management of Asthma National Heart, Lung, and Blood Institute, Bethesda, MD (2007) (NIH publication no.4051 www.nhlbi.nih.gov/guidelines/asthma/asthgd ln.htm (Accessed on December 31, 2018). [18]Vlasić Z1, Dodig S, Cepelak I, Topić RZ, Zivcić J, Nogalo B, Turkalj M:Iron and ferritin concentrations in exhaled breath condensate of children with asthma.J Asthma. 2009 Feb;46(1):81-5. doi: 10.1080/02770900802513007. [19]BTS/SIGN Asthma Guidelines British Guideline on the Management of Asthma Thorax, 63 (Suppl 4) (2008), p. iv1.

[20]Porsbjerg C, von Linstow ML, Ulrik CS, et al. Risk factors for onset of asthma: a 12year prospective follow-up study. Chest 2006; 129:309.

[21]Maazi H, Shirinbak S, Bloksma N, Nawijn MC, van Oosterhout AJM (2011) Iron administration reduces airway hyperreactivity and eosinophilia in a mouse model of allergic asthma. Clin Exp Immunol166: 80-86. 